\title{
EFFECTS OF N FERTILIZATION ON SOIL MICROBIAL RESPIRATION IN LARIX GMELINII PLANTATION
}

\author{
JiA, S. X. ${ }^{1}-$ HU, C. Q. ${ }^{2}-$ SUN, Y. ${ }^{2}-$ HAN, J. ${ }^{2}-$ ZHANG, W. L. ${ }^{1}-$ CHEN, X. W. ${ }^{1}-$ LIANG, A. Z. ${ }^{1}-$ \\ ZHANG, S. X. ${ }^{1 *}$ \\ ${ }^{I}$ Key Laboratory of Mollisols Agroecology, Northeast Institute of Geography and Agroecology, \\ Chinese Academy of Sciences, 130102 Changchun, China \\ ${ }^{2}$ Jilin Provincial Academy of Forestry Sciences, 130033 Changchun, China \\ *Corresponding author \\ e-mail: zhangshixiu@neigae.ac.cn \\ (Received $15^{\text {th }}$ Jun 2018; accepted $14^{\text {th }}$ Aug 2018)
}

\begin{abstract}
Soil organic carbon decomposition is regulated by soil physical and chemical properties, such as soil nitrogen $(\mathrm{N})$ and soil substrate quality. In this study, soil samples from both $\mathrm{N}$ fertilization and control plots were collected at two depths in a Larix gmelinii plantation to determine if $\mathrm{N}$ addition elicits consistent responses in microbial respiration in bulk and rhizosphere soil, and to determine the temporal and spatial dynamics of soil organic carbon decomposition. Soil bulk and rhizosphere microbial respiration were determined using the $\mathrm{NaOH}$ solution absorption method. Soil microbial biomass was determined by a modified $\mathrm{CHCL}_{3}$ fumigation-extraction method. The greatest soil bulk and rhizosphere microbial respiration occurred in July. Soil rhizosphere microbial respiration was higher than bulk respiration at 0-10 cm and 10$20 \mathrm{~cm}$. The biggest reductions in soil microbial respiration induced by fertilization were $15.0 \%$ (bulk) and $19.6 \%$ (rhizosphere) at $0-10 \mathrm{~cm}$ in July, and 6.4\% (bulk) and 7.9\% (rhizosphere) at 10-20 cm in September. Fertilization did not influence the rhizosphere priming effect except for at 10-20 cm in May. Structural equation modeling revealed that soil microbial biomass carbon (MBC) and nitrogen (MBN) contributed directly to soil microbial respiration. Moreover, soil total $\mathrm{N}$ and organic carbon content were associated with soil microbial respiration through $\mathrm{MBC}$ and $\mathrm{MBN}$. These results suggest that $\mathrm{N}$ fertilization suppresses soil organic carbon decomposition by decreasing soil microbial biomass, while $\mathrm{C}$ input induced by root exudates determined the rhizosphere priming effect, not soil microbes in the rhizosphere.
\end{abstract}

Keywords: soil microbe, rhizosphere, soil $N$ availability, soil organic carbon decomposition

\section{Introduction}

Soil is a large organic carbon pool $\left(1.5 \cdot 10^{18} \mathrm{~g}\right.$ of $\left.\mathrm{C}\right)$, containing twice the total $\mathrm{C}$ in the atmosphere (Schlesinger, 1997). The decomposition of soil organic carbon occurs via the microbial assimilation process known as soil microbial respiration, which is one of the most important processes in global carbon cycling (Schimel and Schaeffer, 2012), response to the primary decomposed ability of new carbon associated to soil by plant (Schlesinger, 1997). Therefore, the decomposition ratio of soil C pools is regulated by soil physical and chemical properties (Xu et al., 2016). Soil nutrient availability, particularly that of nitrogen $(\mathrm{N})$, has been suggested as a key driver of soil organic carbon decomposition (Zhou et al., 2014), such that the soils with a high $\mathrm{C}: \mathrm{N}$ ratio showing lower decomposition rates ( $\mathrm{Xu}$ et al., 2016). Recent studies have shown that nitrogen addition reduced soil microbial respiration induced by the negative effects of $\mathrm{N}$ application on soil microbial abundance and composition (Zhang et al., 2018), as well as that of soil microbial activity by shifting the metabolic capabilities of soil bacterial communities (Ramirez et al., 2012). These results suggest that $\mathrm{N}$ addition slows soil organic carbon decomposition by decelerating microbial mineralization. Therefore, a better 
understanding of soil microbial responses to $\mathrm{N}$ addition is critical to predicting soil carbon sequestration in terrestrial ecosystems.

Soil substrate quality controls the soil organic carbon mineralization and efficiency of soil organic carbon microbial assimilation (Manzoni et al., 2008, 2012), with a higher substrate quality leading to higher microbial assimilation, large microbial biomass (Blagodatskaya et al., 2011), and a higher ratio of microbial carbon to soil organic carbon (Xu et al., 2014). Plant root exudates and other labile root-derived rhizodeposit are important substrates for soil microbes (Haichar et al., 2014). For example, the soil adjacent to roots has larger $\mathrm{C}$ mineralization rates than bulk soil in undisturbed temperate forest sites (Phillips and Fahey, 2007). A meta-analysis showed that input of labile organic $\mathrm{C}$ to the rhizosphere can stimulate soil organic carbon decomposition by $59 \%$ (Huo et al., 2017), and this process may be regulated by changes in the size and composition of the microbial community (Dorodnikov et al., 2009; Talbot et al., 2008). This is likely because there is $14-31 \%$ higher microbial biomass (Blagodatskaya et al., 2014) and an order of magnitude higher microbial activity and abundance in the rhizosphere than in bulk soil (Kuzyakov and $\mathrm{Xu}, 2013$ ). However, few studies have investigated the rhizosphere soil microbial activity when there is no more ongoing labile organic $\mathrm{C}$ input under $\mathrm{N}$ addition.

Therefore, the present study was conducted to determine if $\mathrm{N}$ addition elicits consistent responses in microbial respiration in bulk and rhizosphere soil, and to determine the temporal and spatial dynamics of soil organic carbon decomposition. To accomplish this, soils were collected from a larch plantation (Larix gmelinii) during the growing season and incubated under laboratory conditions. We expected that soil microbial activity under $\mathrm{N}$ fertilization would mitigate any increases in soil organic carbon decomposition induced by rhizosphere microbes. We also hypothesized that changes in microbial biomass would result in concurrent changes in soil microbial respiration.

\section{Materials and methods}

\section{Study site}

This study was conducted at the Maoershan Experimental Station $\left(127^{\circ} 30^{\prime}-127^{\circ} 34^{\prime} \mathrm{E}\right.$, $\left.45^{\circ} 21^{\prime}-45^{\circ} 25^{\prime} \mathrm{N}\right)$ of Northeast Forestry University, Heilongjiang Province, China (Fig. 1).

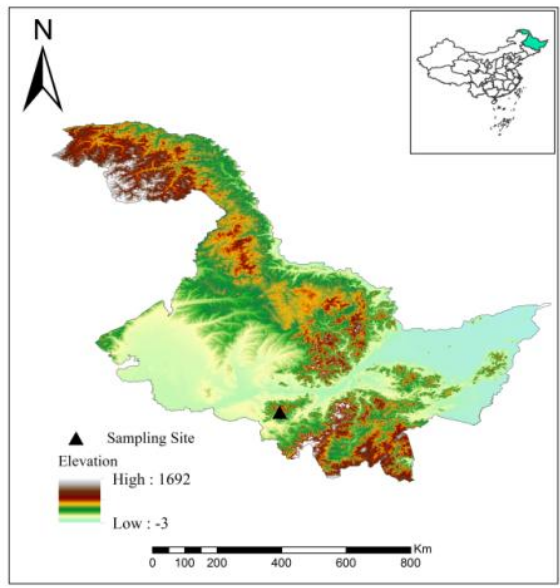

Figure 1. The sampling site of the experiment 
This region is characterized by a cold, temperate-zone, continental monsoonal climate. The average annual temperature is $2.8^{\circ} \mathrm{C}$, with average daily air temperatures ranging from $-19.6{ }^{\circ} \mathrm{C}$ (January) to $20.9{ }^{\circ} \mathrm{C}$ (July). The mean annual precipitation is $723 \mathrm{~mm}$, with 66\% (477 mm) occurring in June, July and August. Additionally, the mean annual evapotranspiration is $1,094 \mathrm{~mm}$. The soil (Hap-Boric Luvisol) is usually frozen to a depth of $1 \mathrm{~m}$ in winter (December-April). More details about the soil in the region are given by Wang et al. (2006).

\section{Experimental design}

The experiment was designed to test the fertilization treatment effects on soil and plantations. L. gmelinii and Fraxinus mandshurica with representing 65\% and $10 \%$ of conifer and hardwood plantations are both dominant species in natural forests of Northeast China and key commercial plantation specie. Two plantations were established in 1986 by planting 2-year-old seedlings using a 1.5-2.0 m planting grid. The experiment was arranged in a randomized design in each plantation in May of 2002, and all plots were $20 \mathrm{~m} \times 30 \mathrm{~m}$. Each stand had two $\mathrm{N}\left(\mathrm{NH}_{4} \mathrm{NO}_{3}\right)$ fertilization treatments, control plots $\left(0 \mathrm{~g} \mathrm{~N} \cdot \mathrm{m}^{-2} \cdot \mathrm{y}^{-1}\right)$ and fertilized plots $\left(10 \mathrm{~g} \mathrm{~N} \cdot \mathrm{m}^{-2} \cdot \mathrm{y}^{-1}\right)$, and each treatment was applied in triplicate. The fertilizer was applied continuously on the 15th of each month from 2003 until sampling year (2014) in amounts set based on soil temperatures (Table 1). All measurements were performed after the fertilizer had been applied for two weeks. In the present experiment, only the L. gmelinii plantation of the parent experiment was sampled.

Table 1. Soil temperature at different soil depth of research site

\begin{tabular}{c|c|c|c|c}
\hline \multirow{2}{*}{ Season } & \multicolumn{2}{|c|}{ Soil temperature different depths $\left({ }^{\circ} \mathbf{C}\right)$} & \multirow{2}{*}{ Fertilizer amount (\%) } \\
\cline { 2 - 4 } & $\mathbf{5 ~ c m}$ & $\mathbf{1 0} \mathbf{~ c m}$ & $\mathbf{2 0} \mathbf{~ c m}$ & 15.25 \\
\hline May & 12.50 & 9.70 & 8.70 & 21.00 \\
June & 19.50 & 17.20 & 16.30 & 27.50 \\
July & 22.30 & 20.60 & 19.90 & 21.00 \\
August & 22.10 & 21.00 & 20.80 & 15.25 \\
September & 14.60 & 16.00 & 14.60 & \\
\hline
\end{tabular}

\section{Soil sampling}

Six soil samples were collected from each plot using soil cores with a $6 \mathrm{~cm}$ inner diameter at depths of 0-10 cm and 10-20 cm in May, July, and September of 2014. Samples were separated into bulk and rhizosphere soil. To accomplish this, rhizosphere soil was collected from the soil tightly adhering to fine roots $(<2 \mathrm{~mm}$ in diameter) as described by Wang and Zabowski (1998). Briefly, the soil not tightly adhering to roots was first removed by gently shaking the roots, then tightly adhered soil was collected by putting the roots into a paper bag and vigorously shaking them. Bulk samples were obtained from pooled soil by mixing thoroughly after fine root and rhizosphere soil removal. Soil samples were transported to the research station in a cooler $\left(\sim 4{ }^{\circ} \mathrm{C}\right)$, then sieved $(<2 \mathrm{~mm})$ to remove stones, coarse and fine roots and stored at $4{ }^{\circ} \mathrm{C}$. 


\section{Soil microbial biomass}

Soil microbial biomass was determined by a modified $\mathrm{CHCL}_{3}$ fumigation-extraction method (Vance et al., 1987). The $\mathrm{C}$ and $\mathrm{N}$ content that were $\mathrm{K}_{2} \mathrm{SO}_{4}$-extracted from the $\mathrm{CHCL}_{3}$-fumigated and unfumigated soils were estimated using a TOC-VCPH analyzer (Shimadzu, Tokyo, Japan), and soil microbial biomass C (MBC) and soil microbial biomass $\mathrm{N}(\mathrm{MBN})$ were calculated using extraction factors of 0.45 and 0.54 , respectively (Brookes et al., 1985; Vance et al., 1987).

\section{Soil microbial respiration}

The microbial (basal) respiration (including bulk and rhizosphere soil) was determined based on the soil $\mathrm{CO}_{2}$ emissions over a $10 \mathrm{~d}$ incubation period. Briefly, $20 \mathrm{~g}$ soil samples adjusted to $60 \%$ of the water holding capacity were incubated in $1000 \mathrm{~cm}^{3}$ gas-tight jars at $20{ }^{\circ} \mathrm{C} \pm 2{ }^{\circ} \mathrm{C}$. The $\mathrm{CO}_{2}$ was then absorbed by $\mathrm{NaOH}$ solution $(0.05 \mathrm{M})$ and $\mathrm{CO}_{2}$ was determined by single end-point titration with $\mathrm{HCl}$ following addition of $400 \mu 1$ of $0.5 \mathrm{M} \mathrm{BaCl}_{2}$, and precipitated as barium carbonate, after which the amount of $\mathrm{CO}_{2}$ was calculated (Bekku et al., 1997; Phillips and Fahey, 2007).

\section{Soil properties}

Soil total $\mathrm{C}$ and $\mathrm{N}$ were determined using a FlashEA 1112 elemental analyzer (Thermo Finnigan, Italy). Soil $\mathrm{pH}$ was measured in a 1:5 soil: water solution using a FiveEasy pH meter (Mettler-Toledo Ltd., Mississauga, Canada). Soil $\mathrm{NO}_{3}^{-} \mathrm{N}$ and $\mathrm{NH}_{4}^{+}$ $\mathrm{N}$ were extracted using $2 \mathrm{M} \mathrm{KCl}$ and were determined with an 8500 series flow injection autoanalyzer (Hach Company, Loveland, USA).

\section{Data analysis}

Repeated measures ANOVA was conducted to assess the effects of fertilization on soil microbial respiration using the SPSS statistical software 11.5 (SPSS Inc., Chicago, USA). When the results of ANOVA demonstrated a statistically significant difference, Tukey's test was conducted to assess the effects of fertilization treatments. A $P<0.05$ was considered to indicate statistical significance.

Structural equation modeling (SEM) was used to evaluate the general hypothesis that soil microbial biomass $(\mathrm{C}, \mathrm{N})$, soil organic carbon, total $\mathrm{N}, \mathrm{NO}_{3}{ }^{-} \mathrm{N}, \mathrm{NH}_{4}{ }^{+}-\mathrm{N}$ and $\mathrm{pH}$ influence soil microbial respiration in response to fertilizer application. We constructed an a priori model including possible causal relationships among predictors. Those eight predicators in the initial model were treated as observed variables. Mardia's test was then used to estimate the multivariate normality of the dataset, and the model fit was assessed using the $\chi^{2}$-test, comparative fit index (CFI), and root mean square error of approximation (RMSEA). Analyses were performed with the SPSS AMOS 21.0 software (SPSS Inc., Hong Kong, China) using the robust maximum likelihood estimation procedures.

\section{Results}

\section{Soil microbial respiration}

Soil bulk and rhizosphere microbial respiration showed similar seasonal dynamics as soil temperature, with the greatest respiration rate occurring in July (Fig. 2). Soil 
microbial (bulk and rhizosphere) respiration varied with soil depths. Specifically, the surface $(0-10 \mathrm{~cm})$ soil microbial respiration rate was about 4.0 times (bulk: $3.1-4.9)$ and 3.9 (rhizosphere: $3.1-4.6)$ greater than that at $10-20 \mathrm{~cm}(P<0.05)$. Soil rhizosphere microbial respiration was $6.6 \%$ (control) to $6.8 \%$ (fertilized) and $10.0 \%$ (fertilized) to $11.7 \%$ (control) higher than the bulk respiration at $0-10 \mathrm{~cm}$ and $10-20 \mathrm{~cm}(P>0.05)$, respectively. Additionally, the priming effects were positive, being about $6.7 \%$ and $10.9 \%$ at $0-10 \mathrm{~cm}$ and $10-20 \mathrm{~cm}$ (Fig. 2; Table 2).
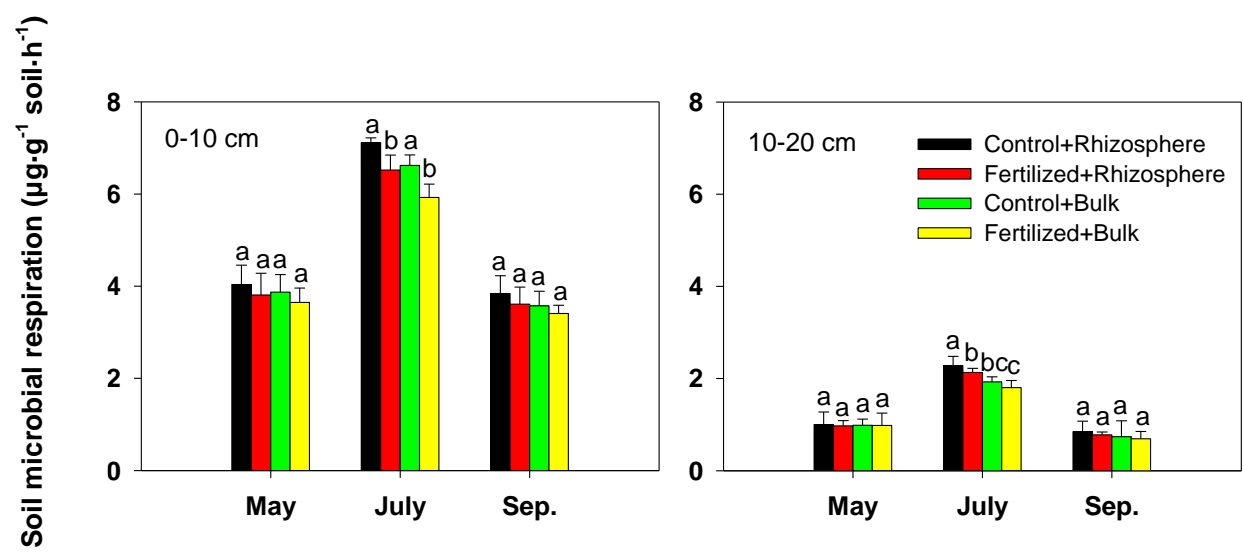

Figure 2. Seasonal dynamical of soil rhizosphere and bulk respiration at surface and subsurface layer

Table 2. Repeated measurement ANOVA of fertilizer and rhizosphere on soil microbial respiration

\begin{tabular}{c|c|c|c|c|c}
\hline \multirow{2}{*}{ Source } & \multirow{2}{*}{ df } & \multicolumn{2}{|c|}{$\mathbf{0 - 1 0} \mathbf{c m}$} & \multicolumn{2}{c}{$\mathbf{1 0 - 2 0} \mathbf{~ c m}$} \\
\cline { 3 - 6 } & & F value & $\boldsymbol{P}$ value & F value & $\boldsymbol{P}$ value \\
\hline Sampling time (S) & 2 & 235.045 & $\mathbf{0 . 0 0 0}$ & 114.102 & $\mathbf{0 . 0 0 0}$ \\
Fertilized (F) & 1 & 8.371 & $\mathbf{0 . 0 4 5}$ & 1.153 & 0.050 \\
Rhizophere (R) & 1 & 6.544 & 0.060 & 5.145 & $\mathbf{0 . 0 4 5}$ \\
$\mathrm{S} \times \mathrm{F}$ & 2 & 1.372 & 0.722 & 0.293 & 0.238 \\
$\mathrm{~S} \times \mathrm{R}$ & 2 & 1.119 & 0.343 & 2.347 & 0.503 \\
$\mathrm{~S} \times \mathrm{F} \times \mathrm{R}$ & 2 & 0.039 & 0.654 & 0.001 & 0.728 \\
Error & 8 & & & & \\
\hline
\end{tabular}

\section{Effect of fertilization on soil microbial respiration}

Fertilization decreased soil bulk and rhizosphere microbial respiration, while its effects on soil microbial respiration varied with sampling time and soil depth (Fig. 2; Table 2). The greatest reductions in soil microbial respiration induced by fertilization of $15.0 \%$ (bulk) and $19.6 \%$ (rhizosphere) occurred in July at $0-10 \mathrm{~cm}$, and by $6.4 \%$ (bulk) and $7.9 \%$ (rhizosphere) at 10-20 cm in September (Fig. 2; Table 2). Fertilization did not influence the rhizosphere priming effect at $0-10 \mathrm{~cm}$ and $10-20 \mathrm{~cm}$ during the growing season except during May at 10-20 cm (Fig. 2). 


\section{Relationship between soil properties and soil microbial respiration}

Structural equation modeling revealed that the predictors explained $88 \%$ of the variation in soil microbial respiration (Rmic) (Fig. 3). Soil MBC and MBN contributed directly to soil microbial respiration, and the response of soil microbial respiration to MBC and MBN differed. Soil total N (STN) and organic carbon (SOC) content were associated with soil microbial respiration through MBC and MBN. It should be noted that fertilization influenced soil microbial respiration indirectly through soil $\mathrm{NO}_{3}^{-}-\mathrm{N}$ and $\mathrm{pH}$.

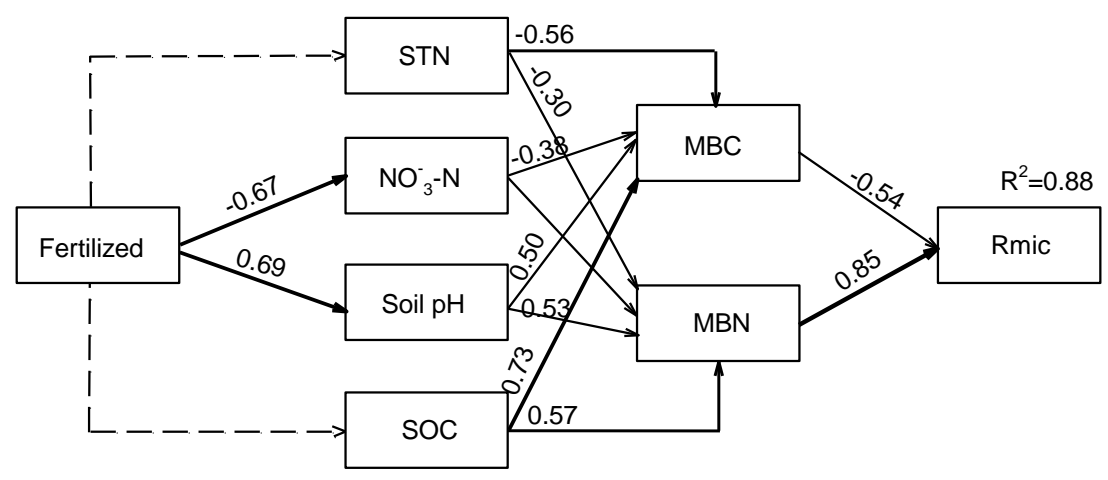

Figure 3. Structural equation model relating fertilization on soil microbial respiration $\left(\chi^{2}=14.385 ; d f=28 ; P=0.695 ; C F I=1.000 ; R M S E A=0.000\right)$. Note: Rectangles represent observed variables; ovals represent latent variables; arrow thickness represents the magnitude of the path coefficient. Solid line arrows represent significant paths $(P<0.05)$, dot lines represent not significantly different $(P>0.05)$. STN: Soil total N; SOC Soil organic carbon; MBC: Soil microbial biomass carbon; MBN: Soil microbial biomass nitrogen; Rmic: Soil microbial respiration

\section{Discussion}

\section{Soil microbial respiration}

Soil microbial respiration showed significant seasonal and soil depth effects. Specifically, the respiration rate was $2.04-4.87 \mu \mathrm{gC} \cdot \mathrm{g}^{-1}$ soil $\cdot \mathrm{h}^{-1}$ and $1.90-4.27 \mu \mathrm{gC} \mathrm{g}{ }^{-1}$ soil $\cdot h^{-1}$ in rhizosphere and bulk soil, respectively, which is consistent with the results of other studies (Ananyeva et al., 2008; Olsson et al., 2005). These seasonal dynamics differed from those of the MBC and MBN (Table 3). This likely occurred because of interspecific competition between plants and microbes for nutrients (Kuzyakov and $\mathrm{Xu}$, 2013), especially for N. In July, soil conditions are beneficial to both soil microbes and plant growth. Soil microbes showed higher respiration rate, indicating they were taking more nutrients for their own and plant growth, leading to decreased biomass accumulation (Fig. 2; Table 3). Soil microbes might utilize available $\mathrm{N}$ more effectively than plants in the short-term, while plants might be more competitive in the long run (Kuzyakov and $\mathrm{Xu}, 2013$ ). Moreover, temporal dynamics of soil microbial biomass are associated with alternating periods of microbial death and growth, which has important consequences for soil nutrient dynamics and soil microbial biomass turnover (Wardle, 1998). The soil microbial respiration rate decreased with declining soil microbial biomass turnover, leading to the accumulation of soil microbial biomass in September (Table 3). Finally, soil microbial biomass and activity determined the soil microbial respiration rates (Xu et al., 2017). A higher soil microbial metabolic quotient $\left(q \mathrm{CO}_{2}\right)$, 
which is defined as the microbial respiration per unit of microbial biomass, indicates higher respiration consumption of carbon and lower construction carbon. The results of the present study showed that the $q \mathrm{CO}_{2}$ value in July was higher than in May and September at depths of both 0-10 and 10-20 cm (Table 4). In general, if microbes are more active during that period, cumulative maintenance respiration should be greater, and the population size should be lower (Brown et al., 2004).

Table 3. Soil microbial biomass $C$ and $N($ mean $\pm S E)$ at surface and subsurface layer

\begin{tabular}{c|c|c|c|c}
\hline Soil depths & Sampling time & Treatment & MBC $(\mathbf{m g} / \mathbf{k g})$ & MBN $(\mathbf{m g} / \mathbf{k g})$ \\
\hline \multirow{4}{*}{$0-10 \mathrm{~cm}$} & \multirow{2}{*}{ May } & Control & $670.85 \pm 77.68$ & $143.16 \pm 17.63$ \\
& & Fertilized & $447.34 \pm 41.68$ & $78.23 \pm 9.38$ \\
\cline { 2 - 5 } & \multirow{2}{*}{ July } & Control & $731.71 \pm 32.18$ & $204.67 \pm 24.67$ \\
& \multirow{2}{*}{ September } & Fertilized & $435.01 \pm 25.28$ & $95.17 \pm 13.16$ \\
\cline { 2 - 5 } & \multirow{2}{*}{ May } & Control & $1106.59 \pm 40.36$ & $223.52 \pm 4.99$ \\
& \multirow{2}{*}{$10-20 \mathrm{~cm}$} & Fertilized & $864.08 \pm 47.30$ & $122.28 \pm 20.03$ \\
\cline { 2 - 5 } & \multirow{2}{*}{ July } & Control & $406.29 \pm 49.79$ & $82.38 \pm 6.28$ \\
& \multirow{2}{*}{ September } & Contilized & $285.57 \pm 5.13$ & $58.88 \pm 7.28$ \\
\cline { 2 - 5 } & & Fertilized & $450.61 \pm 34.71$ & $107.51 \pm 12.07$ \\
\cline { 2 - 5 } & & Control & $731.33 \pm 31.19$ & $64.47 \pm 13.65$ \\
\hline \multirow{2}{*}{} & Fertilized & $649.26 \pm 37.39$ & $128.51 \pm 9.39$ \\
& & & & $97.94 \pm 9.53$ \\
\hline
\end{tabular}

Table 4. Soil microbial respiration metabolic quotient $\left(q \mathrm{CO}_{2}\right)$

\begin{tabular}{c|c|c|c|c|c|c|c}
\hline & \multirow{2}{*}{ Month } & \multicolumn{2}{|c|}{$\mathbf{0 - 1 0} \mathbf{c m}$} & \multicolumn{2}{c|}{$\mathbf{1 0 - 2 0}$ cm } & \multicolumn{2}{c}{$\mathbf{0 - 2 0 ~ c m}$} \\
\cline { 3 - 8 } & & Control & Fertilized & Control & Fertilized & Control & Fertilized \\
\hline Metabolic quotient & May & 5.77 & 8.15 & 2.42 & 3.44 & 4.51 & 6.31 \\
$\left(q \mathrm{CO}_{2}\right)$ & July & 9.05 & 13.62 & 4.07 & 7.47 & 7.23 & 11.44 \\
$\mathrm{mgCO}_{2}-\mathrm{C} \cdot \mathrm{g}^{-1}\left(\mathrm{C}_{\text {mic }}\right) \cdot \mathrm{h}^{-1}$ & Sep. & 3.23 & 3.94 & 1.01 & 1.06 & 2.34 & 2.71 \\
\hline
\end{tabular}

\section{Fertilization effect}

Soil nitrogen availability strongly influences the growth and abundance of soil organisms. The addition of $\mathrm{N}$ has been shown to affect microbial growth, abundance and composition, as well as soil microbial activity (Bowden et al., 2004; Phillips and Fahey, 2007; Zhang et al., 2018), which is consistent with our finding that fertilization decreased soil microbial respiration (Fig. 2). There are several explanations for these results. First, $\mathrm{N}$ fertilization decreased the number of colony forming units of bacteria, fungi, and actinomycetes in our research plot by $98 \%, 63 \%$ and $61 \%$, respectively (Jia et al., 2009). Because the number of colony forming units of soil microbes was positively related to soil $\mathrm{pH}$ (Compton et al., 2004), which declined from 5.18 (control plot) to 4.35 (fertilized plot) in this larch plantation. Moreover, the SEM results revealed that fertilization influenced soil microbial respiration indirectly through soil $\mathrm{pH}$. Second, N fertilization decreased soil microbial biomass (Table 3). Soil MBC and MBN contributed directly to soil microbial respiration (Fig. 3). Because soil microbial biomass turnover was fast under lower soil $\mathrm{pH}$, it would be slower under higher $\mathrm{pH}$ 
(Wardle, 1998). Third, the soil microbial respiration metabolic quotient $\left(\mathrm{qCO}_{2}\right)$ is increasingly being used as an index of ecosystem development and disturbance (Wardle and Ghani, 1995). Nitrogen fertilization increased $\mathrm{qCO}_{2}$ by $42 \%$ (the average of the growing season) at both $0-10$ and $10-20 \mathrm{~cm}$. The increasing $\mathrm{qCO}_{2}$ indicates that microbes invested more in consuming carbon instead of construction carbon. These findings suggested that soil microbes may change their strategy by increasing the function per unit of soil microbial biomass in high nutrient soil. Therefore, $\mathrm{N}$ fertilization decreased microbial respiration because of reduced microbial demand for mining of soil organic carbon for $\mathrm{N}$ uptake.

\section{Rhizosphere effect}

Soil organic carbon is the source of soil microbial respiration. In rhizosphere soil, organic $\mathrm{C}$ derived from living roots consists of soluble and insoluble forms of organic $\mathrm{C}$ such as sugars, organic acids, mucilage, sloughed cell walls and root hairs, providing a carbon- and energy-rich environment (Haichar et al., 2014). This can suppress soil organic carbon decomposition by $50 \%$ or stimulate it by $380 \%$ during incubation in soil without plants (Cheng et al., 2014). Therefore, rhizosphere microbial communities, biomass, activity and abundance are distinct from those not affected by living roots (Blagodatskaya et al., 2014; Garland, 1996). The soil microbial community and biomass in the rhizosphere have been shown to be higher than in bulk soil. For example, Gramnegative, Gram-positive and fungal PLFA abundance in rhizosphere were higher by $45.4 \%, 33.3 \%$ and $66.7 \%$ than in bulk soil, and the average rhizosphere microbial biomass was 3.5 times more than that of bulk soil in a previous study (Paterson et al., 2007). The root exudates and other rhizodeposits can influence physical, chemical, biological and environmental interactions between plants and soils (Cheng et al., 2014; Kuzyakov and Blagodatskaya, 2015), and it is estimated that the quantity of $\mathrm{C}$ released in soil via root exudates ranges from 50 to $1500 \mu \mathrm{g} \mathrm{g}^{-1}$ soil d ${ }^{-1}$ (Cheng, 1996; Jones and Darrah, 1993; Meharg and Kilham, 1991; Trofymow et al., 1987), which may induce higher microbial abundance and diversity and faster microbial growth in rhizosphere soil (Berg and Smalla, 2009; Paterson et al., 2009). Moreover, exudation rates were shown to be positively correlated with organic carbon decomposition in the rhizosphere (Yin et al., 2014). Furthermore, the amount of soil microbial biomass was not closely related to priming (Liu et al., 2017). In the present study, no significant priming effects were observed (Fig. 4), even though the average rhizosphere soil respiration was $6.4 \%$ $(4.0-7.1 \%)$ and $11.7 \%(1.9-18.5 \%)$ higher than that of bulk soil at depths of $0-10$ and 10-20 cm (Fig. 2; Table 2). These findings differ from the previous studies, which showed significantly higher basal respiration in the rhizosphere than root-free soil after glucose addition (Blagodatskaya et al., 2014). Our findings suggest that the C input induced by root exudates determined the occurrence of rhizosphere priming, not soil microbes in the rhizosphere.

The priming effect did not differ significantly between the control and fertilized (except for in May at 10-20 cm) plot in this study (Fig. 4). This may have been because there was no ongoing new $\mathrm{C}$ input in the present study. Indeed, a previous study showed that $\mathrm{N}$ fertilization decreased the decomposition of old and stable soil organic carbon, but did not affect newly deposited C (Zang et al., 2017). However, soil nutrient availability is one of the factors controlling priming effects between soil depths. Greater priming has been observed in low nutrient soils compared with high nutrient soils (Dimassi et al., 2014), which may explain why the rhizosphere effects in July and 
September were higher at $10-20 \mathrm{~cm}$ than at $0-10 \mathrm{~cm}$ (Fig. 4). Another reason may be the lower MBC at 10-20 cm soil, because soils with a higher MBC showed less priming compared to those with a lower MBC (Wang et al., 2015). These results suggest that microbes from deeper soil were less dependent on the $\mathrm{C}$ input derived from roots.

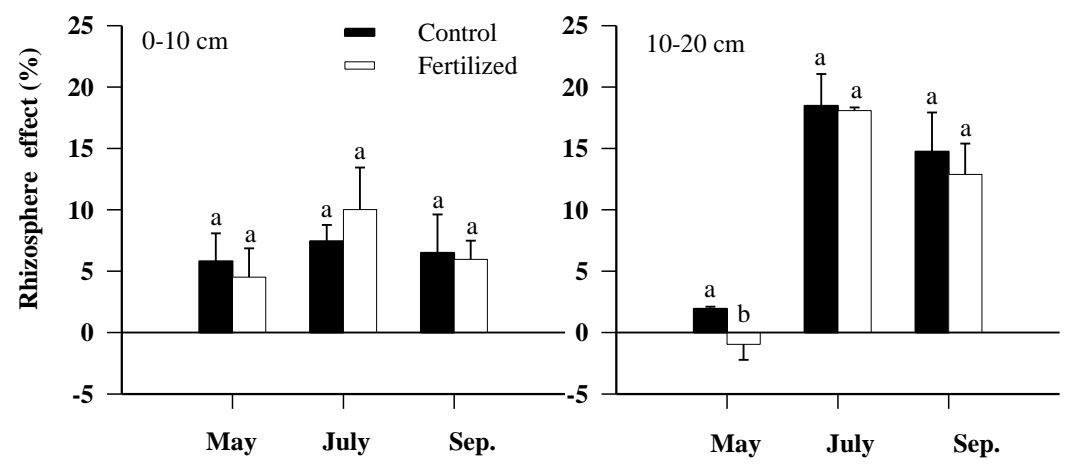

Figure 4. Effect of $N$ fertilization on rhizosphere effect at surface and subsurface layer

\section{Conclusion}

In summary, there was no significant rhizosphere priming effect when there was no ongoing new $\mathrm{C}$ input to soil, even though soil rhizosphere microbial respiration was higher than bulk respiration. Nitrogen fertilization decreased soil bulk and rhizosphere microbial respiration, but did not influence the rhizosphere priming effect. Soil microbial biomass carbon and nitrogen contributed directly to soil microbial respiration. Moreover, soil total $\mathrm{N}$ and organic carbon content were associated with soil microbial respiration through soil microbial biomass. These results suggest that it is not the soil microbes in the rhizosphere that determined the occurrence of rhizosphere soil organic carbon decomposition (priming effect). Soil microbes may change their strategy for mining soil organic carbon under higher soil $\mathrm{N}$ availability.

Acknowledgements. The project was financially supported by Jilin Province Development Program for Sciences and Technology (20160204024NY).

\section{REFERENCES}

[1] Ananyeva, N. D., Susyan, E. A., Chernova, O. V., Wirth, S. (2008): Microbial respiration activities of soil from different climatic regions of European Russia. - European Journal of Soil Biology 44(2): 147-157.

[2] Bekku, Y., Koizumi, H., Oikawa, T., Iwaki, H. (1997): Examination of four methods for measuring soil respiration. - Applied Soil Ecology 5: 247-254.

[3] Berg, G., Smalla, K. (2009): Plant species and soil type cooperatively shape the structure and function of microbial communities in the rhizosphere. - FEMS Microbiology Ecology 68: 1-13.

[4] Blagodatskaya, E., Yuyukina, T., Blagodatsky, S., Kuzyakov, Y. (2011): Turnover of soil organic matter and of microbial biomass under $\mathrm{C} 3-\mathrm{C} 4$ vegetation change: consideration of ${ }^{13} \mathrm{C}$ fractionation and preferential substrate utilization. - Soil Biology and Biochemistry 43: 159-166. 
[5] Blagodatskaya, E., Blagodatsky, S., Anderson, T. H., Kuzyakov, Y. (2014): Microbial growth and carbon use efficiency in the rhizosphere and root-free soil. - PLoS ONE 9(4): e93282.

[6] Bowden, R. D., Davidson, E., Savage, K., Arabia, C., Steudler, P. (2004): Chronic nitrogen additions reduce total soil respiration and microbial respiration in temperate forest soils at the Harvard Forest. - Forest Ecology Management 196: 43-56.

[7] Brookes, P. C., Landman, A., Pruden, G., Jenkinson, D. S. (1985): Chloroform fumigation and the release of soil nitrogen: A rapid direct extraction method to measure microbial biomass nitrogen in Soil. - Soil Biology and Biochemistry 17: 837-842.

[8] Brown, J. H., Gillooly, J. F., Allen, A. P., Savage, V. M., West, G. B. (2004): Toward a metabolic theory of ecology. - Ecology 85: 1771-1789.

[9] Cheng, W. (1996): Measurement of rhizosphere respiration and organic matter decomposition using natural ${ }^{13} \mathrm{C}$. - Plant and Soil 183: 263-268.

[10] Cheng, W. X., Parton, W. J., Gonzalez-Meler, M. A., Phillips, R., Asao, S., McNickle, G., Brzostek, E., Jastrow, J. (2014): Synthesis and modeling perspectives of rhizosphere priming. - New Phytologist 201: 31-44.

[11] Compton, J. E., Watrud, L. S., Porteous, L. A., Degrood, S. (2004): Response of soil microbial biomass and community composition to chronic nitrogen additions at Harvard Forest. - Forest Ecology Management 196: 143-158.

[12] Dimassi, B., Mary, B., Fontaine, S., Perveen, N., Revaillot, S., Cohan, J. P. (2014): Effect of nutrients availability and long-term tillage on priming effect and soil $\mathrm{C}$ mineralization. - Soil Biology and Biochemistry 78: 332-339.

[13] Dorodnikov, M., Blagodatskaya, E., Blagodatsky, S., Fangmeier, A., Kuzyakov, Y. (2009): Stimulation of r- vs. K-selected microorganisms by elevated atmospheric $\mathrm{CO}_{2}$ depends on soil aggregate size: research article. - FEMS Microbiology Ecology 69: 4352 .

[14] Garland, J. L. (1996): Patterns of potential C source utilization by rhizosphere communities. - Soil Biology and Biochemistry 28(2): 223-230.

[15] Haichar, F. Z., Santaella, C., Heulin, T., Achouak, W. (2014): Root exudates mediated interactions belowground. - Soil Biology and Biochemistry 77: 69-80.

[16] Huo, C. F., Luo, Y. Q., Cheng, W. X. (2017): Rhizosphere priming effect: A metaanalysis. - Soil Biology and Biochemistry 111: 78-84.

[17] ISO 14240-1 (1997): Soil Quality-Determination of Soil Microbial Biomass-Part 1: Substrate-Induced Respiration Method. - International Organisation for Standardisation, Geneva.

[18] Jia, S. X., Wang, Z. Q., Li, X. P., Sun, Y., Zhang, X. P., Liang, A. Z. (2010): N fertilization affects on soil respiration, microbial biomass and root respiration in Larix gmelinii and Fraxinus mandshurica plantations in China. - Plant and Soil 333: 325-336.

[19] Jones, D. L., Darrah, P. R. (1993): Re-sorption of organic compounds by roots of Zea mays L. and its consequences in the rhizosphere. II. Experimental and model evidence for simultaneous exudation and re-sorption of soluble C compounds. - Plant and Soil 153: 47-59.

[20] Kuzyakov, Y., Blagodatskaya, E. (2015): Microbial hotspots and hot moments in soil: concept and review. - Soil Biology and Biochemistry 83: 184-199.

[21] Kuzyakov, Y., Xu, X. L. (2013): Competition between roots and microorganisms for nitrogen: mechanisms and ecological relevance. - New Phytologist 198: 656-669.

[22] Liu, X. J., Sun, J. R., Mau, R. L., Finley, B. K., Compson, Z. G., Gestel, N., Brown, J. R., Schwartz, E., Dijkstra, P., Hungate, B. A. (2017): Labile carbon input determines the direction and magnitude of the priming effect. - Applied Soil Ecology 109: 7-13.

[23] Manzoni, S., Jackson, R. B., Trofymow, J. A., Porporato, A. (2008): The global stoichiometry of litter nitrogen mineralization. - Science 321: 684-686. 
[24] Manzoni, S., Taylor, P. G., Richter, A., Porporato, A., Agren, G. I. (2012): Environmental and stoichiometric controls on microbial carbon-use efficiency in soils. New Phytologist 196: 79-91.

[25] Meharg, A. A., Kilham, K. (1991): A novel method of quantifying root exudation in the presence of soil microflora. - Plant and Soil 113: 111-116.

[26] Olsson, P., Linder, S., Giesler, R., Högberg, P. (2005): Fertilization of boreal forest reduces both autotrophic and heterotrophic soil respiration. - Global Change Biology 11: 1745-1753.

[27] Paterson, E., Gebbing, T., Abel, C., Sim, A., Telfer, G. (2007): Rhizodeposition shapes rhizosphere microbial community structure in organic soil. - New Phytologist 173: 600610.

[28] Paterson, E., Midwood, A. J., Millard, P. (2009): Through the eye of the needle: a review of isotope approaches to quantify microbial processes mediating soil carbon balance. New Phytologist 184: 19-33.

[29] Phillips, R. P., Fahey, T. J. (2007): Fertilization effects on fine root biomass, rhizosphere microbes and respiratory fluxes in hardwood forest soils. - New Phytologist 176: 655664.

[30] Ramirez, K. S., Craine, J. M., Fierer, N. (2012): Consistent effects of nitrogen amendments on soil microbial communities and processes across biomes. - Global Change Biology 18: 1918-1927.

[31] Schimel, J. P., Schaeffer, S. M. (2012): Microbial control over carbon cycling in soil. Frontiers in Microbiology 3: 1-11.

[32] Schlesinger, W. H. (1997): Biogeochemistry. - Geotimes 42(2): 44.

[33] Talbot, J. M., Allison, S. D., Treseder, K. K. (2008): Decomposers in disguise: mycorrhizal fungi as regulators of soil $\mathrm{C}$ dynamics in ecosystems under global change. Functional Ecology 22: 955-963.

[34] Trofymow, J. A., Coleman, D. C., Cambardella, C. (1987): Rates of rhizodeposition and ammonium depletion in the rhizosphere of axenic oat roots. - Plant and Soil 97: 333-344.

[35] Vance, E. D., Brookes, P. C., Jenkinson, D. S. (1987): An extraction method for measuring soil microbial biomass-C. - Soil Biology and Biochemistry 19: 703-707.

[36] Wang, H., Xu, W., Hu, G., Dai, W., Jiang, P., Bai, E. (2015): The priming effect of soluble carbon inputs in organic and mineral soils from a temperate forest. - Oecologia 178: $1239-1250$.

[37] Wang, X. P., Zabowski, D. (1998): Nutrient composition of Douglas-fir rhizosphere and bulk soil solutions. - Plant and Soil 200: 13-20.

[38] Wang, Z. Q., Guo, D. L., Wang, X. R., Gu, J. C., Mei, L. (2006): Fine root architecture, morphology and biomass, of different branch orders of two Chinese temperate tree species. - Plant and Soil 288: 155-171.

[39] Wardle, D. A. (1998): Controls of temporal variability of the soil microbial biomass: a global-scale synthesis. - Soil Biology and Biochemistry 30(13): 1627-1637.

[40] Wardle, D. A., Ghani, A. (1995): A critique of the microbial metabolic quotient $\left(\mathrm{qCO}_{2}\right)$ as a bio-indicator of disturbance and ecosystem development. - Soil Biology and Biochemistry 27(12): 1601-1610.

[41] Xu, X., Shi, Z., Li, D. J., Rey, A., Ruan, H. H., Craine, J. M., Liang, J. Y., Zhou, J. Z., Luo, Y. Q. (2016): Soil properties control decomposition of soil organic carbon: Results from data-assimilation analysis. - Geoderma 262: 235-242.

[42] Xu, X. F., Schimel, J. P., Thornton, P. E., Song, X., Yuan, F. M., Goswami, S. (2014): Substrate and environmental controls on microbial assimilation of soil organic carbon: a framework for Earth system models. - Ecology Letter 17: 547-555.

[43] Xu, X. F., Schimel, J. P., Janssens, I. A., Song, X., Song, C. C., Yu, G. R., Sinsabaugh, R. L., Tang, D. D., Zhang, X. C., Thornton, P. E. (2017): Global pattern and controls of soil microbial metabolic quotient. - Ecological Monographs 87(3): 429-441. 
[44] Yin, H. J., Wheeler, E., Phillips, R. P. (2014): Root-induced changes in nutrient cycling in forests depend on exudation rates. - Soil Biology and Biochemistry 78: 213-221.

[45] Zang, H. D., Blagodatskaya, E., Wang, J. Y., Xu, X. L., Kuzyakov, Y. (2017): Nitrogen fertilization increases rhizodeposit incorporation into microbial biomass and reduces soil organic matter losses. - Biology and Fertility of Soils 53(4): 419-429.

[46] Zhang, T. A., Chen, H. Y. H., Ruan, H. H. (2018): Global negative effects of nitrogen deposition on soil microbes. - The ISME Journal. DOI: 10.1038/s41396-018-0096-y.

[47] Zhou, L., Zhou, X., Zhang, B., Lu, M., Luo, Y., Liu, L., Li, B. (2014): Different responses of soil respiration and its components to nitrogen addition among biomes: a meta-analysis. - Global Change Biology 20(7): 2332-2343. 